\title{
Dossiê "Memória, verdade e justiça"
}

Cristina Buarque de Hollanda

Ouso dizer que o leitor tem um tesouro nas mãos. O dossiê "Memória, verdade e justiça" reúne entrevistas com um punhado de personagens centrais do movimento homônimo. Ele o movimento - nem sempre se chamou assim, nem tampouco tem ou teve um corpo bem delimitado de atores, ideias, estruturas e mecanismos. Sempre teve as fronteiras abertas, enlaçadas com outros movimentos, sem doutrina dura ou códigos de acesso. Organizou-se e desorganizou-se nas brechas e bordas do Estado, no seu coração e também no lado de fora dele. Seus integrantes - mesmo que não soubessem sê-lo - uniram-se nos afetos e desafetos que nascem das lutas e adversidades. Divergiram sobre um bocado de coisas, mas convergiram em torno da ideia de que a condição de olhar para frente é olhar para trás; de que do passado não se faz tábula rasa; de que é preciso lembrar e conhecer a ditadura para que "nunca mais se esqueça, nunca mais aconteça".

Nos mais de 40 anos de vida do movimento, há quem tenha se mantido nas suas raias, quem tenha ido e vindo, quem tenha ficado com um pé dentro e outro fora e também quem tenha saído para nunca mais voltar. Não é um clube com filiação e carteirinha, mas uma história bem contada dele não ficaria de pé sem a ação, o discurso e a disposição combativa de Amelinha Teles, Iara Xavier Pereira, Nilmário Miranda, Gilney Vianna, Luiz Eduardo Greenhalgh e Tarso Genro. Não ficaria de pé também sem um olhar atento ao seu front acadêmico, que ganhou fôlego a partir dos anos 2010 e teve e tem em Leonilde Medeiros uma de suas figuras de proa. Por fim, nas suas camadas de renovação, incluiu novas e vigorosas gerações. Um deles foi Paulo Fonteles Filho, triste e precocemente roubado do nosso convívio por um infarto. Pois são essas grandes e esses grandes que estão reunidos aqui.

Este dossiê é um passo no sentido de divulgar entrevistas semi-estruturadas e em profundidade que tenho conduzido nos últimos anos no âmbito de um projeto de pesquisa sobre o que a democracia fez dos legados da ditadura; sobre com que instrumentos e em que termos a militância contra o arbítrio militar se enraizou no novo regime. Quem quiser me acompanhar mais longe nessa jornada, pode também buscar as entrevistas com Crimeia de Almeidai, Luiza Erundinai", Paulo Abrãoiii, Manoel Severino de Moraesiv, Dorival Santos``, Norton Nohamavi, Paulo Nunes ${ }^{\text {vii }}$ e Adriano Diogo viii. Outras ainda virão.

O leitor que se der ao luxo de percorrer todo o dossiê poderá observar a diversidade dos pontos de observação, das opiniões e dos vocabulários dos entrevistados. Grosso modo, eles se distribuem em três eixos de militância, com superposições. Duas mulheres, Amelinha e Iara, representam uma luta que foi desde sempre e sobretudo feminina: a dos familiares de mortos e desaparecidos, em constante e tensa interlocução com políticas de Estado. Elas respondem pelo primeiro eixo. O segundo eixo, o da "luta institucional", como definiu Gilney Viana, é aqui representado por ele próprio, por Nilmário Miranda, Luiz Eduardo Greenhalgh e Tarso Genro. Com histórias bastante diferentes de resistência à ditadura - fora, dentro e por meio dos seus marcos e instrumentos legais - eles se dedicaram, em quadros legislativos e de governos, a alçar a pauta dos crimes da ditadura do fundo da cena democrática, para onde foi empurrada em nome do princípio político da reconciliação. Por fim, o terceiro eixo diz respeito a desdobramento recente do movimento por memória, verdade e justiça: a expansão da etiqueta de "violência da ditadura" para designar toda 
sorte de "grave violação de direitos humanos". Nesse novo enquadramento, os atingidos pelo descalabro militar não são apenas os torturados, mortos e desaparecidos políticos. São todos os afetados pela negligência do Estado diante da ação de particulares e/ ou pela ação deliberada do mesmo Estado, mas sem o espírito de retaliação política. Na prática, está-se falando de comunidades de camponeses e indígenas, duramente atingidas pela ditadura e nunca ou muito pouco reconhecidas nessa posição. Paulo Fonteles, Leonilde Medeiros e, novamente Gilney Viana, se encaixam aqui. Eles bagunçam o imaginário consolidado sobre o tipo social do atingido pela ditadura; deslocam o olhar para fora dos grandes centros urbanos da região Sudeste.

Tive a alegria e o privilégio de ter sido recebida por cada uma das entrevistadas e cada um dos entrevistados nos seus ambientes de trabalho e nas suas casas, pessoal ou virtualmente, quando a pandemia se abateu sobre nós. Sou muitíssimo grata à generosidade de todas e todos. Aliás, são figuras cuja marca na vida pública é justamente esta, a da generosidade. Sobra nelas o que falta no Brasil de hoje. Quiçá sirvam de inspiração num presente de distopias.

Para terminar, uma breve nota afetiva: é uma grande satisfação voltar à Revista Estudos Políticos. Depois de editora, na posição confortável de colaboradora. A companhia de Cesar Kiraly sempre me faz bem. Que sorte ele tem de trabalhar agora com Tamires Alves, a quem eu agradeço imensamente o cuidado editorial. Também registro, por fim e com não menos brilho, a colaboração de Naiara Alves, que preparou comigo boa parte deste material.

Cristina Buarque de Hollanda, Professora do Instituto de Estudos Sociais e Políticos.

\section{Notas}

1. Ver Stampa, Inês; Assumpção, San Romanelli; Hollanda, Cristina Buarque de (organizadoras). Arquivos, democracia e ditadura: reflexões a partir dos 10 anos do Centro de Referência Memórias Reveladas do Arquivo Nacional. Curitiba: Editora Appris, 2020.

2. Ver Stampa, Inês; Assumpção, San Romanelli; Hollanda, Cristina Buarque de (organizadoras). Arquivos, democracia e ditadura: reflexões a partir dos 10 anos do Centro de Referência Memórias Reveladas do Arquivo Nacional. Curitiba: Editora Appris, 2020.

3. Ver Justiça de Transição, experiências autoritárias e democracia. Entrevista com Paulo Abrão, por Cristina Buarque de Hollanda. Revista Estudos ÍberoAmericanos, volume 45, número 3, 2019, pp. 76-89. Disponível em: http://revistaseletronicas. pucrs.br/fo/ojs/index.php/ib eroamericana/article/view/35268/18894. Acesso em: $11 / 05 / 2020$.

4. Entrevista com Manoel Severino Moraes [ex-membro da Comissão Estadual da Memória e da Verdade Dom 
Helder Camara, Pernambuco], por Cristina Buarque de Hollanda. Disponível em: https://figshare.com/articles/Entrevista_com_Manoel_ Severino_Moraes_CEMVDHC_/8243123. Acesso em $11 / 05 / 2020$.

5. Entrevista com Dorival Santos [ex-presidente da Comissão Estadual da Verdade do Amapá Francisco das Chagas Bezerra], por Cristina Buarque de Hollanda. Disponível em: https://figshare.com/articles/Entrevista_com_Dorival_ Santos_Comiss_o_Estadual_da_Verdade_do_Amap_/8 307077. Acesso em 11/05/2020.

6. Entrevista com Norton Nohama [ex-membro da Comissão Estadual da Verdade do Paraná Teresa Urban], por Cristina Buarque de Hollanda. Disponível em:

https://figshare.com/articles/Entrevista_com_Norton_ Nohama_Comiss_o_da_Verdade_do_Paran_Teresa_Ur ban $\_8378963$. Acesso em 11/05/2020.

7. Entrevista com Paulo Nunes [ex-membro da Comissão da Verdade e da Preservação da Memória Paraíba], por Cristina Buarque de Hollanda. Disponível em: https://figshare.com/articles/Entrevista_com_Paulo_N unes_Comiss_o_da_Verdade_e_da_Preserva_o_da_M em_ria_Para_ba_/8378969. Acesso em 11/05/2020.

8. Entrevista com Adriano Diogo [ex-presidente Comissão da Assembleia Legislativa do Estado de São Paulo "Rubens Paiva"], por Cristina Buarque de Hollanda. Disponível em: https://figshare.com/articles/Entrevista_com_Adriano_ Diogo_CEV_Rubens_Paiva_SP-SP_/8230727/2 Acesso em: $11 / 05 / 2020$ 